\title{
Frequency of Unintentional Home Injuries in Children under Five Years and its Relation with Environmental Risk Factors, Cairo, Egypt
}

\author{
Hebatullah O Mohammed, Ghada O Wassif, Sally A Hakim, Moustafa E Moustafa
}

Community, Environmental and Occupational Medicine Department, Faculty of Medicine, Ain Shams University.

Received: February, 2018 Accepted: May, 2018

\begin{abstract}
Background: Unintentional home injuries are major cause of morbidity, mortality and disability in children under five years of age. Most of these injuries are preventable through increased awareness, improvements in the home environment safety and caregiver supervision. Objectives: To measure the frequency of unintentional home injuries in children less than five years, to determine its different types, to identify mothers' practices concerning first aid measures in case of occurrence of home injuries \& to compare home environmental safety among home injured and non-injured children. Method: A comparative cross sectional study was conducted among mothers attending pediatric outpatient clinic, Ain Shams university hospital; during the period from February to November 2017; a sample size of 200 mothers were interviewed using structured questionnaire used to collect data about socio-demographic characteristics, frequency, types, place of home injuries, and mother's practice at the time of injury occurrence and the outcomes. Home environmental safety questionnaire adopted from American College of Preventive Medicine, 2014 and Child Injury Assessment Tool were used. Results: 61\% of the participating mothers reported that their children experienced one or more home injuries during the previous year. There was a trend of increasing the proportion of mothers knowledge about first aid measures as the level of education increased. The study identified 5 out of 16 environmental risk factors which were significantly related to different types of home injuries. Conclusion \& recommendation: Unintentional injuries in children under five years could be easily prevented through changing unsafe home environment and changing individual behaviors and norms.
\end{abstract}

Key words: Unintentional home injury, Children under 5 years, First aid.

Corresponding author: Hebatullah Osama Mohammed Sobhy $\quad$ Email: Hebatullah.o.diab@gmail.com

\section{Introduction}

Unintentional injuries are the most common cause of preventable morbidity and mortality among children, and a major public health problem. ${ }^{1}$ Annually, 830,000 children died due to home injuries worldwide, corresponding 2,000 child deaths per day. Again, millions of children referred to hospital due to injuries caused by accidents, resulting in lifelong disabilities. ${ }^{2}$ In Egypt; it has become a concern, several studies were carried out in Egypt to estimate the magnitude of home injuries as a study carried out in Sharkia Governorate at 2014 and showed that the prevalence of home injuries among preschool children in a rural area was $(84.7 \%) .{ }^{3}$ Children are exposed to injury risk as they grow, learn and explore new things surrounding them. The likelihood of a child being injured is associated with a variety of factors including low education among mothers, very young mothers, poor housing, large family size and parental drug or alcohol abuse. ${ }^{4}$ The common mechanisms of home injury are falls, cut 
wounds, fire and burns, choking, suffocation, drowning, poisoning and firearms. Falls account for the majority of non-fatal home injuries while the highest numbers of deaths are due to fire. The largest number of accidents happens in the living room. However, the most serious accidents happen in the kitchen and on the stairs. ${ }^{5}$ Most home injuries happen where there's water in the bathroom, kitchen, or hot tubs. Heat or flames: in the kitchen or at a barbecue grill. Toxic substances: under the kitchen sink, in the medicine cabinet, or even in a purse or other place where medications are stored. Potential for a fall: fall from bed, sofa or crib on stairs, slippery floors, from high windows, or from tipping furniture. ${ }^{6}$ Accordingly, as child lacks of capability to protect himself/herself from accidents, it is responsibility of adults to provide safe environment, to take protective measure and to audit safety of living spaces of children. ${ }^{7}$ Parents' knowledge and practice about first aid measures is especially important in prevention of deaths due to home injuries and improving patient outcome in general. First aid is the provision of initial care for an illness or injury, usually by a non-expert but trained person, until medical treatment can be accessed. Provision of immediate first aid to patients who require emergency care can make a big difference to the outcome. ${ }^{8}$

The aim of the Study is to measure the frequency of unintentional home injuries in Children under Five Years, to determine the different types of home injuries among children under five years at pediatric outpatient clinic in Ain Shams university hospital, to identify mothers' practices concerning first aid measures in case of occurrence of home injuries \& to compare home environmental safety among home injured and non-injured children.
Study type: A comparative cross sectional study was conducted at pediatric hospital outpatient clinic, Ain Shams University, Egypt, during the period from February to November 2017. Study population: Mothers attending pediatric outpatient clinic, Ain Shams university hospital. Inclusion criteria: mothers who have a pre-school child (1-5 years old) and agree to participate in the study. Exclusion criteria: Mothers who have children suffering from chronic debilitating disease e.g. nutritional diseases, cancer and blood diseases and who have children with special needs, including children with physical and/or mental disabilities. Sampling technique: A systematic random sample of mothers attending pediatric outpatient clinic who had one or more child under five years were recruited; the researcher visited the outpatient clinic on two alternating days each week to obtain the required information. Sample size: In estimating the proportion of under 5 injuries, a proposed $50 \%$ will yield the maximum sample size of 182 which produces a two-sided $95 \%$ confidence interval with a width equal to 0.15 . In the comparative part of the study, group sample sizes of 94 in group one and 94 in group two achieve $80 \%$ power to detect a difference between the group proportions of 0.20 giving rise to odds ratio of 2.5 . The exposure to a risk factor is proposed to $50 \%$ and $70 \%$ in the two groups respectively. The test statistic used is the two-sided $\mathrm{Z}$ test with pooled variance. The significance level of the test was targeted at 0.05 . Accordingly, a sample size of 200 individuals was chosen for this study. Study tools: 1- Structured interview questionnaire was used to collect data from participating mothers attending pediatric outpatient clinic. The questionnaire includes the following sections: Section I: Sociodemographic characteristics of the studied mothers e.g. (age, education, occupation, Marital status, family income, child age, child sex, child rank). Section II: Frequency,

\section{Method}


types, cause, place of home injuries, mother's practice at the time of injury occurrence and the outcomes ('cured', 'under treatment with no long-term consequences', 'long-term consequences" disabled"' and death). Section III: Assessment of home environmental safety regarding areas where most home injuries occur (kitchen, bathroom, living and bedroom). The home environmental safety questionnaire was adopted from American College of Preventive Medicine, 2014: Child Injury Assessment Tool ${ }^{(9) .}$ 2- Health Education Booklet designed by the researcher was used to deliver a concise targeted health education message to the interviewed mothers in case of mentioning incorrect action done for her injured child. Pilot study: A pilot study was conducted on $(10 \%)$ of the calculated sample size and was then excluded from the analysis as questionnaire was modified to be more comprehensive and to allow data collection within a reasonable time (not exceeding 15 minutes).

Data Management and Analysis: The collected data was revised, coded, tabulated and introduced to personal computer then analyzed using SPSS program (Statistical Package for Social Sciences) for windows Version 22. Qualitative data were presented as frequencies and percentages, while quantitative variables were presented as mean, standard deviation (SD). Chi square test and fissure exact test were used as tests of significance. $\mathrm{P} \leq 0.05$ was considered significant.

\section{Ethical Consideration: Ethical} committee board of Faculty of Medicine and Ain Shams hospital and administrative approval from pediatric hospital manager were obtained. Verbal Informed consent was taken from each participant. The confidentiality of data was assured.

\section{Results}

The current study included 200 mothers who were attending pediatric hospital outpatient clinic. Ain shams university; Concerning characteristics of the studied mothers; more than half of the mothers $(59 \%)$ were in middle age (25-35 years); their mean age was $29.78 \pm 5.62$ years, More than one quarter of the studied mothers $(26.5 \%)$ were illiterate/read and write, More than two thirds $(68.0 \%)$ were living in urban areas, the majority (82\%) were house wives, In addition to that; $(31.5 \%)$ had three children while (22.0\%) had four children or more, Moreover; half of the studied mothers $(50.0 \%)$ had one child under 5 years and (44.5\%) had two children under five years (Table 1). Regarding the frequency of home injuries, the current study showed that $(61 \%)$ of children under 5 years experienced one or more home injuries in the previous year (Figure 1). Concerning children under five who experienced home injury, less than half $(47.9 \%)$ of the children were in the age group"25-48 months". Boys have higher injury rates than girls it was found that nearly two thirds of them were boys $(62.3 \%)$. The rank of the injured child was the first in about one third of the situations $(33.6 \%)$; the majority of injuries $(93.4 \%)$ occurred despite paternal presence at the place of injury (Table 2). The most frequently encountered types of injuries were fall $(33.6 \%)$, cut wound $(13.9 \%)$, scald (9.8\%), and burn injuries $(8.2 \%)$. the least reported injury was electrical burn $(1.6 \%)$. Drowning, gas suffocation and strangulation were not reported in this study. Concerning the place of injury; Two third of injuries $(67.2 \%)$ occurred in living room, followed by the kitchen $(13.1 \%)$. The majority of the injured children $(70.5 \%)$ received correct action in form of proper first aid measure often by mother or other family member, transferred to the nearby health care facility or sought medical care in a private clinic. Those who didn't seek any 
Table (1): characteristics of the studied mothers $(n=200)$

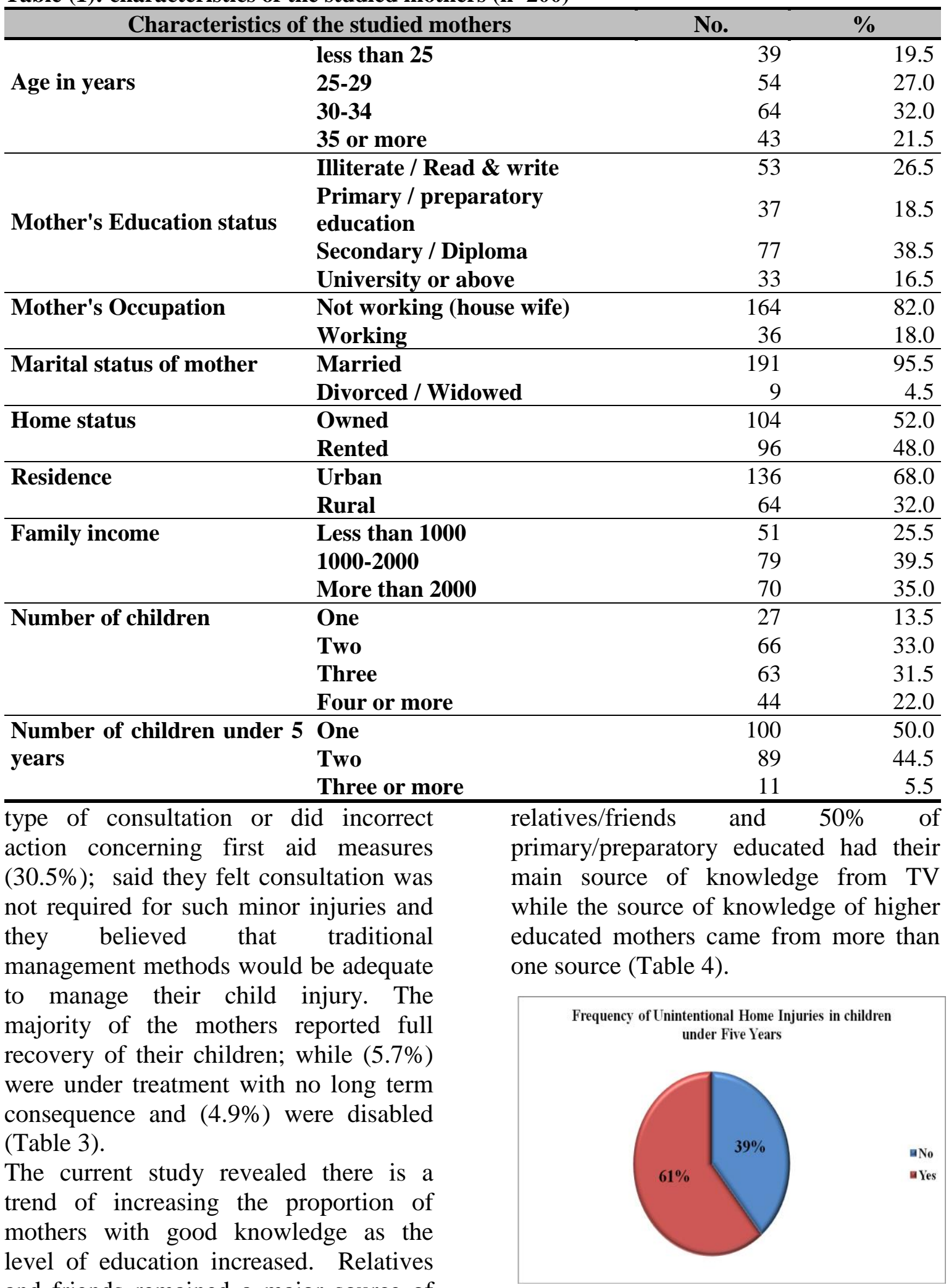
and friends remained a major source of information in those with good knowledge about first aid measures. As the level of education increased the source of knowledge became more versatile, e.g., $63.6 \%$ of Illiterate had their knowledge from the

Figure (1): Frequency of Unintentional home injuries in children under five years

Concerning the Relationship between different types of unintentional home injuries occurred in children under 5 
Table (2): characteristics of home injured child ( $n=122)$

\begin{tabular}{llrr}
\hline \multicolumn{2}{c}{$\begin{array}{c}\text { Characteristics of home } \\
\text { injured child }\end{array}$} & No. & \% \\
\hline child age in & $\mathbf{1 - 1 2}$ & 11 & 9.1 \\
months & $\mathbf{1 3 - 2 4}$ & 26 & 21.5 \\
& $\mathbf{2 5 - 4 8}$ & 58 & 47.9 \\
& $\mathbf{4 9 - 6 0}$ & 27 & 21.5 \\
\hline Child gender & Male & 76 & 62.3 \\
& Female & 46 & 37.7 \\
\hline & First & 41 & 33.6 \\
& Second & 29 & 23.8 \\
Child rank & Third & 31 & 25.4 \\
& Fourth & 13 & 10.7 \\
& Fifth or more & 8 & 6.6 \\
\hline Child alone & No & 114 & 93.4 \\
at the time of & Yes & 8 & 6.6 \\
the injury & Yes &
\end{tabular}

years and home environmental safety measures; the present study found that there was a statistically significant relationship between foreign body aspiration in the studied children and keeping small round toys at home, where $(10.6 \%)$ of mothers who keep small toys at home within reachable areas; their children had foreign body aspiration. There was a statistically significant relationship between occurrence of electric burns in the studied children and leaving electric outlets uncovered where $(3.4 \%)$ of mothers who left electric outlets uncovered and kept electric appliances within reach of children in their home; their children had electric burn injuries. In addition to that; there was a statistically significant relationship between occurrence of burns and holding children by mothers while cooking; where $(9.7 \%)$ of mothers who hold their children while cooking; their children had burns. Moreover; there was a statistically significant relationship between occurrence of child poisoning and keeping cleaning products and medications within the reach of children; where $(20.9 \%$ and $12.5 \%)$ of mothers who keep household chemical cleaning products and medications respectively within reach; their children had poisoning (Table 5).

\section{Discussion}

Children under 5 years old are less aware of danger and they are more vulnerable group to have an unintentional home injury. Most home injuries are presumed to be preventable through removal of particular hazards. Child safety remains an important concern of parents nowadays (LeBlanc et al., 2006). ${ }^{10}$ The present study showed that more than one quarter $(26.5 \%)$ of the participating mothers were illiterate or read and write and about (38.5\%) had diploma or secondary education while higher education represented by $(16.5 \%)$. This finding is in agreement with Mohammed et al., $2013^{11}$ who conducted a study in two university hospitals "Cairo University Specialized Pediatric Hospital and Benha University Hospital" and found that less than $(20.0 \%)$ were illiterate, more than $(40.0 \%)$ of the mothers had secondary education while higher education represented (20.0\%). The agreement with Mohammed et al., $2013^{11}$ was due to studying mothers from pediatric hospital at Cairo and Benha University which are related to similar socioeconomic level. The present study revealed that the prevalence of unintentional home injury among the studied under five years children was $(61.0 \%)$ over the previous 1-year period. This result nearly agrees with a previous study conducted by Ibrahim, $2004^{12}$ who carried out a study in El-Fateh district, Assiut Governorate and revealed that the incidence rates of home injuries were (60.0\%) and with Abd El Aty et al, $2005^{13}$ in Assiut governorate, where the prevalence of home injuries among children under six years was $(50.3 \%)$. On the other hand, the current figure was lower in study conducted by Eldosoky, $2012^{14}$ in Qalubeya governorate, who described the prevalence of home related injuries among children as (38.3\%). In addition to another study conducted by Kamal, $2013^{15}$ in El-Minia governorate, which showed that only $(20.6 \%)$ of the 
Table (3): Characteristics of home related injuries $(n=122)$

\begin{tabular}{|c|c|c|c|}
\hline & Variables & No. & $\%$ \\
\hline \multirow{13}{*}{ Type of injury } & Fall & 41 & 33.6 \\
\hline & Cut wound & 17 & 13.9 \\
\hline & Burn & 10 & 8.2 \\
\hline & Scald & 12 & 9.8 \\
\hline & Electric burn & 3 & 2.5 \\
\hline & Poisoning & 9 & 7.4 \\
\hline & Choking, Foreign body Aspiration & 16 & 13.1 \\
\hline & Drowning & 0 & 0.0 \\
\hline & Stepping on a sharp object & 0 & 0.0 \\
\hline & Gas suffocation & 0 & 0.0 \\
\hline & Strangulation & 0 & 0.0 \\
\hline & Hit by object & 6 & 4.9 \\
\hline & Others* & 8 & 6.6 \\
\hline \multirow[t]{5}{*}{ Place Of injury } & Kitchen & 16 & 13.1 \\
\hline & Bathroom & 4 & 3.3 \\
\hline & Living room & 82 & 67.2 \\
\hline & Children's bedroom & 8 & 6.6 \\
\hline & Adult's bedroom & 12 & 9.8 \\
\hline \multirow{2}{*}{$\begin{array}{l}\text { Injury repeated in } \\
\text { last year }\end{array}$} & No & 104 & 85.2 \\
\hline & Yes & 18 & 14.8 \\
\hline \multirow{2}{*}{$\begin{array}{ll}\text { Mothers' } & \text { Action } \\
\text { towards } & \text { injury } \\
\text { occurrence } & \end{array}$} & Correct & 86 & 70.5 \\
\hline & Incorrect & 36 & 29.5 \\
\hline \multirow{2}{*}{$\begin{array}{ll}\text { Admission } & \text { to } \\
\text { hospital due } \\
\text { injury }\end{array}$} & No & 118 & 96.7 \\
\hline & Yes & 4 & 3.3 \\
\hline \multirow{6}{*}{$\begin{array}{l}\text { Outcome of the } \\
\text { injury }\end{array}$} & Complete recovery & 106 & 86.9 \\
\hline & $\begin{array}{l}\text { Under treatment with no long term } \\
\text { consequence }\end{array}$ & 7 & 5.7 \\
\hline & Disabled & 6 & 4.9 \\
\hline & Psychological trauma & 1 & 0.8 \\
\hline & Death & 1 & 0.8 \\
\hline & Broken teeth & 1 & 0.8 \\
\hline
\end{tabular}

*Insertion of foreign body into ear and nose, animal bite.

children under 5 of age included in the study $a l$., $2013^{11}$ who found that the mean age of had a home injury over the previous 1-year $3.32 \pm 1.181$ years was the age highest period. This difference may be attributed to prevalence of home injuries. This is also in the difference in the age of the studied accordance with El-sabely et al., $2014^{16}$ who children (for example Eldosoky, 2012 ${ }^{14}$ measured measure the incidence of home injuries affecting rural children aged up to 12 years), different methodology, different study setting (urban versus rural) and different definition of home related injury. The present study revealed that nearly half $(47.9 \%)$ of the children who had a home injury were from 2-4 years old as children move freely at home in this age. This result was further agreed with a study conducted in Cairo, by Mohammed et revealed that more than half of injured children $(59.3 \%)$ were aged $\leq 3$ years, this may be due to the fact that the younger the child, the higher the frequency of household injuries. Regarding sex differences, the study showed that nearly two thirds $(62.3 \%)$ of home injured children were boys. This result agreed with Zaidi et al., $2013^{17}$ who carried out a study in India and found that boys experienced more home 
Table (4): Relationship between mother educational level and knowledge of first aid among mothers $(\mathbf{n}=\mathbf{2 0 0})$

\begin{tabular}{|c|c|c|c|c|c|c|c|c|c|c|}
\hline \multicolumn{9}{|c|}{ Mothers' Educational level } & \multirow{3}{*}{$\begin{array}{c}\text { Chi square } \\
\text { test }\end{array}$} & \multirow{3}{*}{ P-value } \\
\hline \multirow{3}{*}{$\begin{array}{l}\text { Knowledge of first aid } \\
\text { measures }\end{array}$} & \multicolumn{2}{|c|}{$\begin{array}{c}\text { Illiterate / } \\
\text { Read \& } \\
\text { write } \\
\end{array}$} & \multicolumn{2}{|c|}{$\begin{array}{c}\text { Primary / } \\
\text { preparator } \\
\text { y education }\end{array}$} & \multicolumn{2}{|c|}{$\begin{array}{c}\text { Secondary / } \\
\text { Diploma }\end{array}$} & \multicolumn{2}{|c|}{$\begin{array}{l}\text { University } \\
\text { or above }\end{array}$} & & \\
\hline & No. & $\%$ & No. & $\%$ & No. & $\%$ & No. & $\%$ & & \\
\hline & 11 & 20.8 & 6 & 16.2 & 22 & 28.6 & 25 & 75.8 & 36.770 & $<0.001 * *$ \\
\hline Source of knowledge & No. & $\%$ & No. & $\%$ & No. & $\%$ & No. & $\%$ & $\begin{array}{l}\text { Fisher } \\
\text { exact test } \\
(\#)\end{array}$ & P-value \\
\hline Books & 0 & 0.0 & 0 & 0.0 & 0 & 0.0 & 1 & 4.0 & & \\
\hline Part of curriculum & 0 & 0.0 & 1 & 16.7 & 2 & 9.1 & 4 & 16.0 & & \\
\hline Relatives / Friends & 7 & 63.6 & 1 & 16.7 & 7 & 31.8 & 7 & 28.0 & & \\
\hline Doctors/Nurses & 2 & 18.2 & 0 & 0.0 & 8 & 36.4 & 1 & 4.0 & 32.963 & $0.05 *$ \\
\hline Television & 2 & 18.2 & 3 & 50.0 & 1 & 4.5 & 4 & 16.0 & & \\
\hline Training course & 0 & 0.0 & 1 & 16.7 & 3 & 13.6 & 6 & 24.0 & & \\
\hline Internet & 0 & 0.0 & 0 & 0.0 & 1 & 4.5 & 2 & 8.0 & & \\
\hline
\end{tabular}

(*) Statistically significant at $\left.P<0.05 .,^{* *}\right)$ Highly statistically significant at $P<0.01$. (\#) Fisher Exact test was used as the expected count in (20.0\%) of the cells or more are less than 5

related injuries than girls (65\% versus $35 \%$ ) respectively. El-sabely et al., $2014^{16}$ also found that more than half of the injured children were boys $(58.7 \%)$ than girls $(41.3 \%)$. This result also agreed with Eldosoky, $2012^{13}$ who found that the incidence rate of home accidents constituted $(57.5 \%)$ for boys and $(42.5 \%)$ for girls. Also similar to the study in Turkey done by Oztürk $C$ et al., $2010^{18}$ found the prevalence was $(53.4 \%$ and $46.6 \%$ respectively). Previous studies proved that boys have increased risktaking behavior than girls; in addition to the influence of their peer which would increase their risk to experience more home injuries. Regarding the type of home related injury, the current study revealed that falls represented the highest percentage of injury (33.6\%) followed by cut wounds $(13.9 \%)$ then scald $(9.8 \%)$ and burn $(8.2 \%)$. This conforms with many previous studies as Alptekin, $2008^{20}$ in Turkey, Zaidi et al., $2013^{17}$ in India, Mohammed et al., $2013^{11}$ in Cairo and Shriyan, 2014 ${ }^{19}$ in India who found that falls are the most predominant type of home injuries among under five year children $(38.4 \%, 32.4 \%, 72 \%$ \& $54.5 \%)$ respectively. This might be attributed to unsafe home environment for children and lack of mother supervision when doing daily activities at home. On the contrary to our results, other studies revealed that that cut wound represented the highest percentage of home injuries among the under five year children as Ibrahim, 2004 ${ }^{12}$ in Assiut governorate, Abd El-Aty et al., 2005 ${ }^{13}$, Eldosoky, $2012^{14}$ in Qalubeya governorate and Megahed et al., $2016^{21}$ in Menoufia governorate $(35.5 \%, 37.4 \%, 31 \% \&$ $68.9 \%$ ) respectively. Regarding the place of the occurrence of injuries at home, the current study demonstrated that two third of injury (67.2\%) occurred in living room while The kitchen represented the second most common place for injuries (13.1\%); as Egyptian families used to spent most of their times in the living room watching television and leaving their children to move freely without strict supervision. This is in agreement with a study conducted in Turkey done by Alptekin, $2008^{20}$ who revealed that $(30 \%)$ of the injuries occurred in the living room followed by the kitchen (26.7\%); while the bathroom or the toilet had the third rank. The majority of the participating mothers (93.4\%) reported that they were present with their children at time of injury occurrence and only (6.6\%) reported that the child was alone. This finding was supported by Shriyan, 
Table (5): Relationship between different types of unintentional home injuries among children and home environmental safety measures $(n=200)$

\begin{tabular}{|c|c|c|c|c|c|c|}
\hline $\begin{array}{c}\text { Home environmental safety } \\
\text { measures }\end{array}$ & \multicolumn{4}{|c|}{ Foreign Body Aspiration } & $\begin{array}{c}\text { Fisher exact } \\
\text { test } \\
(\#)\end{array}$ & $P$ value \\
\hline \multirow{2}{*}{$\begin{array}{l}\text { Mother keeps small round toys in } \\
\text { home }\end{array}$} & \multicolumn{2}{|c|}{ No } & \multicolumn{2}{|c|}{ Yes } & \multirow{4}{*}{5.614} & \multirow{4}{*}{$0.043^{*}$} \\
\hline & No. & $\%$ & No. & $\%$ & & \\
\hline No & 57 & 98.3 & 1 & 1.7 & & \\
\hline Yes & 127 & 89.4 & 15 & 10.6 & & \\
\hline \multirow{3}{*}{ Leave electrical outlets uncovered } & \multicolumn{4}{|c|}{ Electric burn } & \multirow{3}{*}{$\begin{array}{c}\text { Fisher exact } \\
\text { test } \\
(\#)\end{array}$} & \multirow[b]{3}{*}{ P value } \\
\hline & \multicolumn{2}{|c|}{ No } & \multicolumn{2}{|c|}{ Yes } & & \\
\hline & No. & $\%$ & No. & $\%$ & & \\
\hline No & 110 & 100.0 & 0 & 0.0 & \multirow{2}{*}{4.780} & \multirow{2}{*}{$0.029 *$} \\
\hline Yes & 87 & 96.6 & 3 & 3.4 & & \\
\hline \multirow{3}{*}{ Hold child while cooking } & \multicolumn{4}{|c|}{ Burn } & - Fisher exact & \multirow{3}{*}{ P value } \\
\hline & \multicolumn{2}{|c|}{ No } & \multicolumn{2}{|c|}{ Yes } & test & \\
\hline & No. & $\%$ & No. & $\%$ & (\#) & \\
\hline No & 97 & 100.0 & 0 & 0.0 & 13767 & $<0 \Omega 01 * *$ \\
\hline Yes & 93 & 90.3 & 10 & 9.7 & & $<0.001 \cdots$ \\
\hline $\begin{array}{l}\text { Leave child in the kitchen alone } \\
\text { while cooking }\end{array}$ & No. & $\%$ & No. & $\%$ & $\begin{array}{l}\text { Fisher exact } \\
\text { test (\#) }\end{array}$ & $P$ value \\
\hline No & 164 & 94.3 & 10 & 5.7 & & \\
\hline Yes & 26 & 100.0 & 0 & 0.0 & & 0.268 \\
\hline \multirow{3}{*}{$\begin{array}{l}\text { Storage cleaning supplies in a safe } \\
\text { closed place }\end{array}$} & \multicolumn{4}{|c|}{ Poisoning } & \multirow{3}{*}{ Fisher exact } & \multirow{3}{*}{ P value } \\
\hline & \multicolumn{2}{|c|}{ No } & \multicolumn{2}{|c|}{ Yes } & & \\
\hline & No. & $\%$ & No. & $\%$ & & \\
\hline No & 34 & 79.1 & 9 & 20.9 & -34409 & $<0001 * *$ \\
\hline Yes & 157 & 100.0 & 0 & 0.0 & & $<0.001 \cdots$ \\
\hline
\end{tabular}

Keep medications in safe closed No. \% No. $\% \quad \begin{aligned} & \text { Fisher exact } \\ & \text { test (\#) }\end{aligned}$
place value

\begin{tabular}{|c|c|c|c|c|c|}
\hline No & 63 & 87.5 & 9 & 12.5 & $<0 \Omega 01 * *$ \\
\hline Yes & 128 & 100.0 & 0 & $0.0^{10.154}$ & $<0.001 \%$ \\
\hline
\end{tabular}

(*) Statistically significant at $P<0.05$. , (**) Highly statistically significant at $P<0.01$. (\#) Fisher Exact test was used as the expected count in (20.0\%) of the cells or more are less than 5

$2014^{19}$ in India who reported that injuries do occur despite of the presence of adults as they didn't have the knowledge on how to prevent injuries among their children while carrying their daily activities in the same time. The current study found that mothers' education level was the only significant characteristic that affects mothers' knowledge regarding first aid measures for child home injuries. More than three fourth of the highly educated mothers $(75.8 \%)$ were aware about first aid measures. This results agreed with Megahed et al., $2016^{21}$ who reported that, mothers' knowledge score was higher with increased level of education, as (64.3\%) of mothers who had satisfactory knowledge had high education, whereas $(2.9 \%)$ of mothers who had satisfactory knowledge were illiterate. Furthermore; El-Sabely et al., $2014^{16}$ in Sharkia governorate, Egypt, mentioned that illiterate mothers had poor knowledge on first aid of home accidents among children. The same finding was obtained from the study conducted in Turkey by Oztürk C et al., $2010^{18}$ who reported that there was a meaningful relationship between mothers' educational status and 
knowledge and practice regarding child home injuries. In this study, we aimed to determine home environmental safety level and its relation with type of injury occurred. In the case of the association between risk factors relative to infrastructure home environment and domestic injuries, it was revealed that five out of sixteen variables $(31.25 \%)$ were significantly related to different types of home injuries $(\mathrm{P}<0.05)$; presence of medications and vitamins within reach of children; presence of cleaning supplies within reach of children; uncovered electrical outlets which accessible by the child; holding child while cooking and giving children round, hard and small food. Identifying environmental risk factors related to unsafe home environment and its related type of injury would raise an alarm to mitigate these factors as being modifiable through proper health education messages to the participating mothers to prevent further occurrence of such injuries in the future. De Assis Brito et al., 2016 $6^{22}$ in Brazil represented other risk factors for the occurrence of home injuries: presence of stairs or steps without handrail; presence of thorns, nails, broken glass and other items in the area where the child plays; presence of plants and garden or yard. The difference in environmental risk factors may be attributed to different cultures between countries. This reality shows that injury prevention in childhood goes beyond the emotional care of children, and must encompass economic determinants, which provide a safer environment (Pereira and Garcia 2009). ${ }^{23}$

\section{Conclusions and recommendations}

The study concluded that unintentional injuries in children under five years could be easily prevented through changing unsafe home environment and changing individual behaviors and norms. Strengthening mothers' knowledge about first aid measures targeting unintentional home injuries immediately after their occurrence would improve injury outcome and would prevent the occurrence of disabilities or leaving residual effects in the children that would affect their quality of life later on.

\section{References}

1. Yousefzadeh, S. H., HEMATI, H., Alizadeh, A., Karimi, A., Ahmadi, M., \& MOHAMMADI, H. (2008). Pediatric Unintentional Injuries in North of Iran. Iranian Journal of Pediatrics, 18(3), 267-271.

2. Peden, M. M. (Ed.). (2008). World report on child injury prevention. World Health Organization, 20 Avenue Appia, 1211 Geneva 27, Switzerland.

3. Sabely, A. A. E., Yassin, A. E. I., \& Zaher, S. A. (2014). Mother's Education and her Knowledge about Home Accident Prevention among Preschool Children in Rural Area in Sharkia Governorate. IOSR J Nursing Health Sci, 3, 32-40.

4. Thein M.M., Lee B.W., and Bun P.Y., (2005). Childhood injuries in Singapore: a community nationwide study, Singapore Med. J., 46: pp.116-21.

5. Unit, C. S. (2002). 24th annual report, home accident surveillance system. London: Department of Trade and Industry.

6. Morrison A., and Stone D.H., (2009). Unintentional childhood injury mortality in Europe: a report from the EURORISC Working Group, Injury Prevention; 5(3): pp.171-176

7. Akturk, Ü. \& Erci, B. (2016). Determination of Knowledge, Attitudes and Behaviors Regarding Factors Causing Home Accidents and Prevention in Mothers with a Child Aged 0-5 Years. Journal of Education and Practice, 7(18), 142-153.

8. Kendrick, D., Coupland, C., Mulvaney, C., Simpson, J., Smith, S. J., Sutton, A\& Woods, A. (2007). Home safety education and provision of safety equipment for injury prevention. Cochrane Database Syst Rev, 1(1).

9. American College of Preventive Medicine, 2014: Child Injury Assessment Tool.

(http://c.ymcdn.com/sites/www.acpm.org/res 
ource/resmgr/Andrea/ChildInjuryAssessment Tool-Fi.pdf) accessed at 3rd February 2018. 10. LeBlanc, J. C., Pless, I. B., King, W. J., Bawden, H., Bernard-Bonnin, A. C., Klassen, T., \& Tenenbein, M. (2006). Home safety measures and the risk of unintentional injury among young children: a multicentre case-control study. Canadian Medical Association Journal, 175(8), 883-887.

11. Mohammed, A. R., Mohammed, N. S., \& Byoumi, M. H. (2013). Supportive strategies regarding accidents prevention for mothers of children under five years old. JBAH, 3, 111.

12. Ibrahim H H, (2004). "Investigative epidemiology of childhood accidents in ElFateh district", Assiut Governorate, Upper Egypt. Unpublished Doctor Thesis In Public Health, Faculty of Medicine, Assiut University.

13. Abd El-Aty, N. S. A., Moftah, F. M., Ibrahim, H. D. F., \& Hassanen, R. H. (2005). Assessment of Knowledge and Practice of Mothers Toward Home Accidents Among Children Under Six Years In Rural Areas In Assiut Governorate (2003). Ass. Univ. Bull. Environ. Res, 8(2).

14. Eldosoky, R. S. H. (2012). Home-related injuries among children: knowledge, attitudes and practice about first aid among rural mothers. Eastern Mediterranean health journal, 18(10), 1021.

15. Kamal, N. N. (2013). Home unintentional non-fatal injury among children under 5 years of age in a rural area, El Minia Governorate, Egypt. Journal of community health, 38(5), 873-879.

16. El-sabely, A. A., Yassin, A. E. A. I., \& Zaher, S. A. (2014). Mother's Education and Her Knowledge about Home Accident Prevention among Preschool Children in Rural Area in Shakira Governorate. IOSR
Journal of Nursing and Health Science, 3, $32-40$

17. Zaidi SHN, Khan Z, Khalique N. (2013). Injury pattern in children: a population based study. Indian journal of community health, 25:45-51.

18. Öztürk, C., Sari, H. Y., Bektaş, M., \& Elçıg1l, A. (2010). Home Accidents And Mothers Measurements In Preschool Children. Anatolian Journal of Clinical Investigation, 415-21. (1).

19. Shriyan, P., Prabhu, V., Aithal, K. S., Yadav, U. N., \& Orgochukwu, M. J. (2014). Profile of unintentional injury among underfive children in coastal Karnataka, India: a cross-sectional study.Age (years),3(18),40-9. 20. Alptekin, F., Uskun, E., Kisioglu, A. N., \& Ozturk, M. (2008). Unintentional nonfatal home-related injuries in Central Anatolia, Turkey: frequencies, characteristics, and outcomes. Injury, 39(5), 535-546.

21. Megahed, M. A., Khalil, N. A., Ibrahem, R. A., \& El Disoki, R. S. (2016). Knowledge, attitude and practice of rural mothers towards home injuries among children under 5 years of age in Menouf District-Menoufia Governorate, Egypt. Menoufia Medical Journal, 29(4), 1033.

22. De Assis Brito, M., Da Rocha, S. S., Borges, J. W. P., De Araújo, T. M. E., de Oliveira Gouveia, M. T., do Amaral Gubert, F, \& Pinheiro, M. T. M. (2016). Risk Factors for Occurrence of Domestic Accidents Involving Children under the Age of Five: Implications for Nursing Care. International Archives of Medicine, 9.

23. Pereira SFA, Garcia CA. (2009). Domestic accident prevention in childhood. Rev. Enferm UNISA. 10(2): 172-7. 